\title{
KAJIAN MINUMAN FERMENTASI DAUN JERUK NIPIS (Citrus aurantiifolia (Christm.) Swingle) MENGGUNAKAN BAKTERI ASAM LAKTAT
}

\section{STUDY OF KEY LIME LEAVES (Citrus aurantiifolia (Christm.) Swingle) FERMENTED BEVERAGE WITH LACTIC ACID BACTERIA}

\author{
AJN Parhusip ${ }^{1 a}$, R Montana1 ${ }^{1}$ NC Putri ${ }^{1}$ \\ ${ }^{1}$ Laboratorium Mikrobiologi-Jurusan Teknologi Pangan Universitas Pelita Harapan; \\ Jl. M. H.Thamrin Boulevard 1100 Lippo Village, Tangerang 15811 - Indonesia. \\ aKorespodensi: Adolf J. N. Parhusip, E-mail: adolf.parhusip@uph.edu
}

(Diterima oleh Dewan Redaksi: 29-08-2017)

(Dipublikasikan oleh Dewan Redaksi: 25-10-2017)

\begin{abstract}
The aim for this research was to examines the characteristics of key lime leaves fermented beverages using Streptococcus thermopilus and Lactobacillus plantarum. Key lime leaves juices was made into four concentrations, that is $2 \%, 3 \%, 4 \%$, and $5 \%$, and $0 \%$ as a control. Key lime leaves juices with concentrations $5 \%$ was chosen based on the highest amount of proportional of key lime leaves in the juices, and then was made into a fermented beverages with 12 different formulations based on sugar and skim milk concentration, that is $4 \%, 6 \%$, $8 \%$, and $10 \%$ for sugar concentration, and $4 \%, 6 \%$, and $8 \%$ for skim milk concentration. Key lime leaves fermented beverages with $4 \%$ sugar and $4 \%$ skim milk was chosen based on $\mathrm{pH}$ value, total titratable acidity, total lactic acid bacteria. The selected fermented product has $18992.77 \mathrm{ppm}$ of total lactic acid. It also has total amounts of antioxidant, phenolics, and flavonoid respectively about $12.47 \mathrm{mgVCE} / \mathrm{L}, 33.49 \mathrm{mgGAE} / 100 \mathrm{ml}$, and $223.75 \mathrm{mgQE} / \mathrm{L}$. Unfortunately, key lime leaves fermented beverage was not preferred by public.
\end{abstract}

Keywords: fermented beverages, key lime leaves, lactic acid bacteria

\begin{abstract}
ABSTRAK
Tujuan dari penelitian ini adalah untuk memeriksa karakteristik dari minuman fermentasi daun jeruk nipis yang menggunakan Streptococcus thermopilus dan Lactobacillus plantarum. Sari daun jeruk nipis dibuat menjadi empat konsentrasi, yaitu 2\%, 3\%, 4\%, dan $5 \%$. Konsentrasi 0\% digunakan sebagai kontrol. Sari daun jeruk nipis dengan konsentrasi $5 \%$ dipilih berdasarkan jumlah proporsional tertinggi daun jeruk nipis dalam jus, dan kemudian dibuat menjadi minuman fermentasi dengan 12 formulasi berbeda berdasarkan konsentrasi gula dan susu skim, yaitu 4\%, 6\%, 8\%, dan 10\% untuk konsentrasi gula dan 4\%, $6 \%$ dan $8 \%$ untuk konsentrasi susu skim. Minuman fermentasi daun jeruk nipis dengan $4 \%$ gula dan $4 \%$ susu skim dipilih berdasarkan nilai $\mathrm{pH}$, total asam tertitrasi, total bakteri asam laktat. Produk fermentasi terpilih dilakukan analisis nutrisi, jumlah asam laktat, kadar antioksidan, dan organoleptik. Hasil menunjukkan bahwa minuman fermentasi daun jeruk nipis adalah produk tanpa lemak dengan total asam laktat 18992.77 ppm. Produk juga memiliki jumlah antioksidan, fenolik dan flavonoid berturut-turut adalah $12.47 \mathrm{mgVCE} / \mathrm{L}$, $33.49 \mathrm{mgGAE} / 100 \mathrm{ml}$, dan $223.75 \mathrm{mgQE} / \mathrm{L}$. Namun minuman fermentasi daun jeruk nipis tidak disukai masyarakat umum.
\end{abstract}

Kata kunci: minuman fermentasi, daun jeruk nipis, bakteri asam laktat

Parhusip AJN, Montana R, Putri NC. 2017. Kajian Minuman Fermentasi Daun Jeruk Nipis (Citrus aurantiifolia (Christm.) Swingle) Menggunakan Bakteri Asam Laktat. Jurnal Agroindustri Halal 3(2): $105-116$ 


\section{PENDAHULUAN}

Jeruk nipis (Citrus aurantiifolia) merupakan tanaman jenis perdu atau semak yang banyak tumbuh di Indonesia (Haq et al. 2010). Penelitian tentang daun jeruk nipis masih terbatas pada potensi daun jeruk nipis sebagai repellent terhadap nyamuk (Murdani 2014), antibakteri (Jamal et al. 2012), dan antioksidan. Daun jeruk nipis mengandung komponen bioaktif, seperti alkaloid, fenolik, saponin, tanin, steroid, flavonoid, dan terpene (Reddy et al. 2012). Kandungan nutrisinya, lalu keberadaannya yang cukup melimpah, serta belum adanya produk pangan olahan dari daun jeruk nipis membuat daun jeruk nipis berpotensi menjadi produk pangan olahan.

Produk minuman yang difermentasi dengan bakteri asam laktat dapat memberikan manfaat kesehatan, seperti mencegah penuaan, mengurangi alergi, dan merawat dinding saluran pencernaan (Thompson 2014). Potensi pemanfaatan dan pengembangan yang dimiliki daun jeruk nipis mendorong dilakukannya penelitian mengenai pembuatan produk minuman fermentasi dengan menggunakan daun jeruk nipis sebagai bahan baku utamanya.

\section{MATERI DAN METODE}

Bahan dasar yang digunakan dalam penelitian ini adalah daun jeruk nipis (Citrus aurantiifolia (Christm.) Swingle) segar yang didapatkan dari kebun di Legenda Wisata, Cibubur, air minum distilasi "Amidis", gula pasir "Gulaku", dan susu skim "Prolac". Kultur yang digunakan dalam penelitian ini adalah Streptococcus thermophilus (ATCC 7122) dan Lactobacillus plantarum (ATCC 6215). Media untuk pertumbuhan kultur bakteri yang digunakan dalam penelitian ini adalah de Man Rogosa Sharpe Agar (MRSA) dan de Man Rogosa Sharpe Broth (MRSB).

Alat-alat yang digunakan dalam penelitian ini adalah cawan Petri, laminar air flow, inkubator, autoclave, colony counter, juice extractor "Philips", refrigerator, water bath, botol kaca, saringan, stopwatch, $\mathrm{pH}$ meter, mikroskop, vortex, spektrofotometer "Thermo Scientific: Genesys 20", dan instrumen HPLC dengan kolom Lichrospher Rp18 250x $4 \mathrm{~mm}$ dan detektor UV/Vis. $200 \mathrm{~nm}$.

\section{Pembuatan Kultur Stok}

Pembuatan kultur stok dilakukan dengan cara menginokulasikan 1 ose kultur induk $S$. thermophilus dan $L$. plantarum ke dalam $10 \mathrm{ml}$ MRSB. Inkubasi dilakukan pada suhu $37^{\circ} \mathrm{C}, 24$ jam. Kultur hasil inkubasi diinokulasikan sebanyak 1 ose ke dalam $6 \mathrm{ml}$ MRSA miring (Mardianto, 2015). Inkubasi kultur dilakukan pada suhu $42^{\circ} \mathrm{C}$ selama 24 jam.

\section{Penentuan Fase Pertumbuhan Kultur Starter}

Fase pertumbuhan kultur starter ditentukan dengan membuat kurva fase pertumbuhan pada interval waktu ke-0, 2, $4,6,8,10,12$, dan 24 jam. kemudian total koloni bakteri dihitung.

\section{Pembuatan Sari Daun Jeruk Nipis}

Daun jeruk nipis segar disortasi berdasarkan kesamaan ukuran, yaitu dengan panjang 5-8 $\mathrm{cm}$ dan lebar 3-5 cm. Daun jeruk nipis dicuci dalam air minum distilasi. Daun ditiriskan selama 1 menit dengan saringan, lalu dimasukkan ke dalam juice extractor untuk diambil sarinya yang akan menjadi bahan dasar dalam pembuatan minuman fermentasi (Subenthiran et al. 2013).

\section{Penentuan Konsentrasi Sari Daun Jeruk Nipis Terpilih}

Konsentrasi sari daun jeruk nipis terpilih ditentukan berdasarkan perhitungan total bakteri asam laktat. Sari daun jeruk nipis dibuat dalam konsentrasi $0,2,3,4$, dan 5\%, kemudian dipasteurisasi pada suhu $80^{\circ} \mathrm{C}$ selama 15 menit. Sebanyak $3 \%$ kultur starter segar dicampurkan ke dalam sari daun jeruk nipis pada konsentrasi tertentu, dan 
didiamkan selama 15 menit. Campuran diinokulasikan pada cawan Petri secara pour plate. Inkubasi dilakukan pada suhu $42^{\circ} \mathrm{C}$ selama 24 jam, kemudian dilakukan perhitungan total bakteri asam laktat.

\section{Penelitian Tahap I}

Sari daun jeruk nipis terpilih ditambahkan dengan susu skim dan gula pada berbagai konsentrasi. Konsentrasi gula yang dipakai adalah 4, 6, 8, dan $10 \%$, dan konsentrasi susu skim yang dipakai adalah 4, 6, dan 8\%. Campuran bahan dipasteurisasi pada suhu $80^{\circ} \mathrm{C}$ selama 15 menit, kemudian ditambahkan kultur starter, S. thermophiles dan L. plantarum, dengan ratio $1: 1$ sebanyak $3 \%$. Fermentasi dilakukan pada suhu $42^{\circ} \mathrm{C}$ selama 12 jam.

Minuman fermentasi daun jeruk nipis dengan berbagai formulasi di analisis total asam tertitrasi, nilai pH (AOAC 2005), dan total bakteri asam laktat (Frank dan Yousef 2004).

\section{Penelitian Tahap II}

(a)

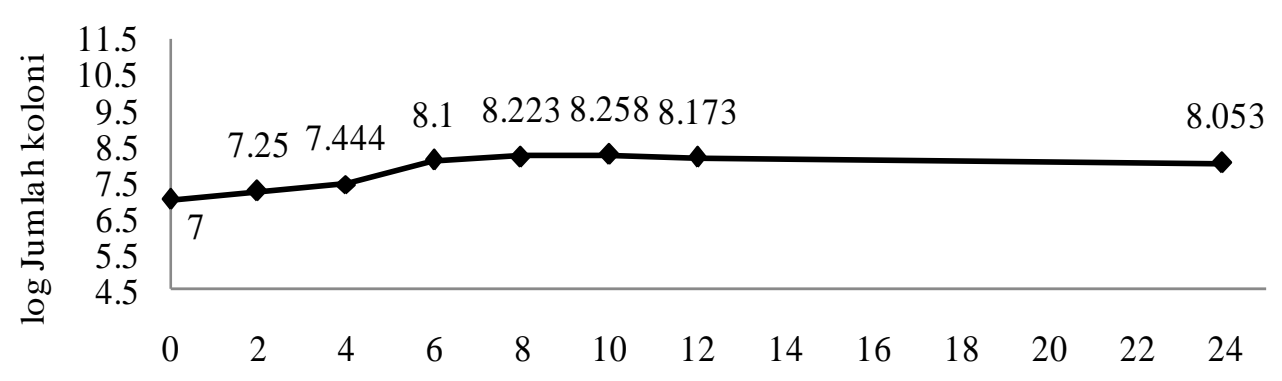

b)

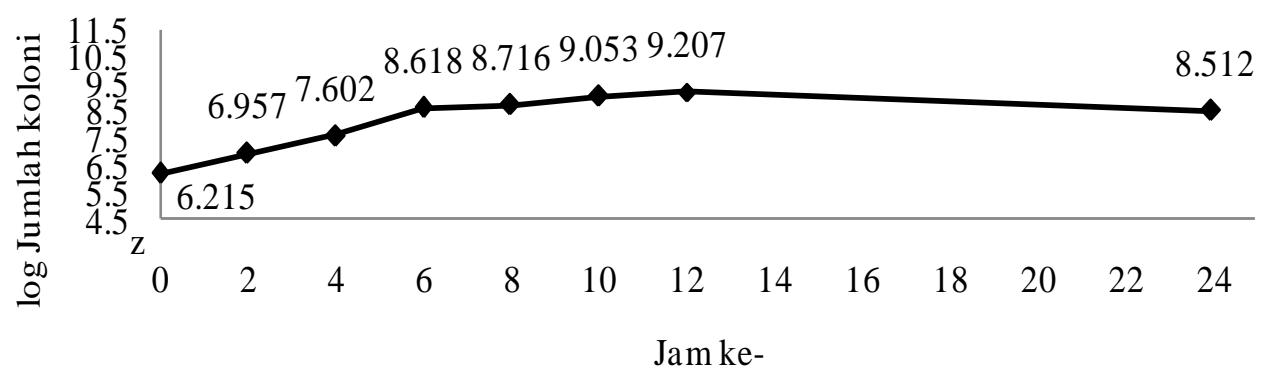

Gambar 1. Kurva pertumbuhan (a) S. thermophilus dan (b) L. plantarum

Berdasarkan Gambar 1, S. 1.26 x $10^{8} \mathrm{CFU} / \mathrm{ml}$, sedangkan waktu thermophilus memasuki fase eksponensial pertumbuhan optimal L. plantarum adalah pada jam ke-4 sampai jam ke-6. Waktu jam ke-10 dengan jumlah sel sebesar 1.13 pertumbuhan optimal $S$. thermophilus x $10^{9} \mathrm{CFU} / \mathrm{ml}$. Waktu pertumbuhan adalah jam ke-6 dengan jumlah sel sebesar optimal kultur starter yang dipilih adalah 6 
jam. L. plantarum belum memasuki fase stasioner pada jam ke-6, namun sel yang $L$. plantarum pada jam ke-6 telah sesuai dengan standar mutu SNI untuk produk minuman fermentasi (2009), yaitu sebesar $4.15 \times 10^{8} \mathrm{CFU} / \mathrm{ml}$, lebih besar dari standar minimal, yaitu 1 x $10^{6} \mathrm{CFU} / \mathrm{ml}$.

\section{Konsentrasi Sari Daun Jeruk Nipis Terpilih}

Konsentrasi sari daun jeruk nipis terpilih ditentukan berdasarkan hasil perhitungan jumlah koloni dari hasil inokulasi dalam sari daun jeruk nipis dengan berbagai konsentrasi, yaitu $0 \%$, $2 \%, 3 \%, 4 \%$, dan 5\%. Hasil uji statistik menunjukkan tidak ada pengaruh signifikan $(p \geq 0.05)$ dari konsentrasi sari daun jeruk nipis terhadap pertumbuhan jumlah koloni $S$. thermophilus atau $L$. plantarum. Pengaruh perbedaan konsentrasi sari daun jeruk nipis terhadap pertumbuhan jumlah sel kultur starter dapat dilihat pada Gambar 2.

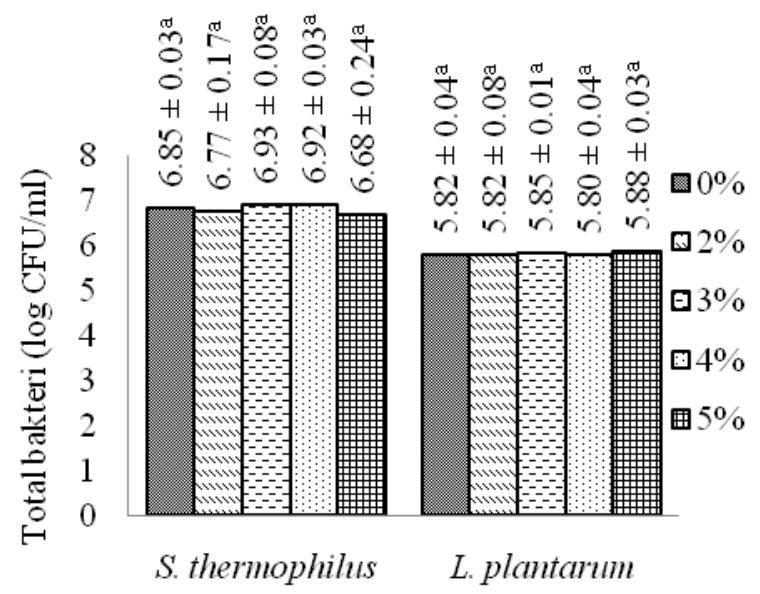

Ket: Notasi huruf superscript yang berbeda pada grafik menunjukkan perbedaan yang signifikan $(p<0.05)$

Gambar 2. Pengaruh konsentrasi sari daun jeruk nipis terhadap pertumbuhan jumlah sel kultur starter.

Daun jeruk nipis mengandung komponen bioaktif, seperti fenolik yang dapat berperan sebagai antimikroba (Caballero et al. 2016). Berdasarkan Gambar 2, pertumbuhan S. thermophilus atau L. plantarum yang diinokulasikan dalam sari daun jeruk nipis tidak mengalami penghambatan seiring meningkatnya konsentrasi sari daun jeruk nipis. Ebnesajjad (2013) menjelaskan bahwa setiap agen/komponen antimikroba memiliki mekanisme penghambatan yang berbeda-beda sehingga setiap komponen antimikroba aktif spesifik hanya terhadap satu atau beberapa mikroorganisme tertentu dan konsentrasi sari daun jeruk nipis terpilih adalah 5\%.

\section{Tingkat Keasaman (Nilai pH)}

Pengaruh perbedaan konsentrasi susu skim terhadap nilai $\mathrm{pH}$ minuman fermentasi daun jeruk nipis dapat dilihat pada Gambar 3.

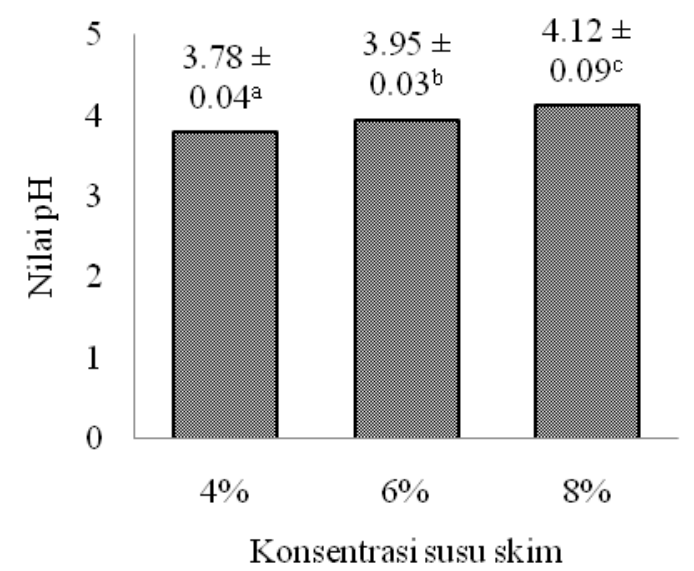

Ket: Notasi huruf superscript yang berbeda pada grafik menunjukkan perbedaan yang signifikan $(p<0.05)$

Gambar 3. Pengaruh konsentrasi susu skim terhadap nilai $\mathrm{pH}$ minuman fermentasi daun jeruk nipis.

Berdasarkan Gambar 3, rata-rata nilai $\mathrm{pH}$ mengalami peningkatan seiring meningkatnya konsentrasi susu. Hasil yang didapat tidak sejalan dengan teori Tamang dan Kailasapathy (2010) dan Soccol et al. (2013) yang menjelaskan bahwa peningkatan konsentrasi susu dapat menyebabkan pertumbuhan bakteri asam laktat semakin subur karena susu mengandung berbagai nutrisi yang 
dibutuhkan untuk pertumbuhan bakteri asam laktat. Metabolisme pembentukkan asam laktat akan mengalami peningkatan sehingga asam laktat yang dihasilkan menjadi semakin banyak dan tingkat keasaman produk juga meningkat.

Nilai pH minuman fermentasi daun jeruk nipis mengalami peningkatan seiring meningkatnya konsentrasi susu dikarenakan susu memiliki nilai $\mathrm{pH}$ netral yaitu \pm 6.6 (Chandan et al. 2008) dan kemampuan sebagai buffer. Jika konsentrasi susu skim semakin besar maka dampak dari proses penetralan akibat pH netral susu akan semakin besar. Proses peningkatan $\mathrm{pH}$ juga diperkuat dengan adanya kemampuan susu sebagai buffer. Perubahan $\mathrm{pH}$ menjadi rendah $\mathrm{(pH}$ asam) akibat terbentuknya asam laktat dapat terhambat karena kemampuan susu sebagai buffer (Zare et al. 2012).

\section{Nilai Total Asam Tertitrasi}

Pengaruh perbedaan konsentrasi susu skim terhadap nilai total asam tertitrasi minuman fermentasi daun jeruk nipis dapat dilihat pada Gambar 4.

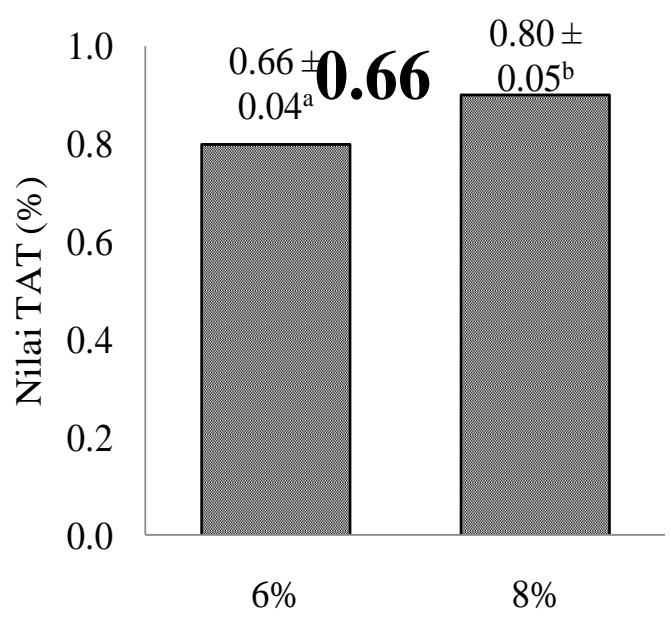

Konsentrasi susu skim

Ket: Notasi huruf superscript yang berbeda pada grafik menunjukkan perbedaan yang signifikan $(\mathrm{p}<0.05)$

Gambar 4. Pengaruh konsentrasi susu skim terhadap nilai TAT minuman fermentasi daun jeruk nipis.
Berdasarkan Gambar 4, nilai total asam tertitrasi mengalami peningkatan seiring meningkatnya konsentrasi susu skim. Tamang dan Kailasapathy (2010) dan Soccol et al. (2013) menjelaskan bahwa pertumbuhan bakteri asam laktat dalam susu dapat menjadi subur sehingga asam laktat yang terbentuk semakin banyak. Banyaknya jumlah bakteri asam laktat dapat menyebabkan banyaknya laktosa yang dikonversi menjadi asam laktat sehingga jumlahnya mengalami peningkatan (Hartati et al. 2012).

\section{Total Bakteri Asam Laktat}

Pengaruh perbedaan konsentrasi susu skim terhadap total bakteri asam laktat ditampilkan dalam Gambar 5.

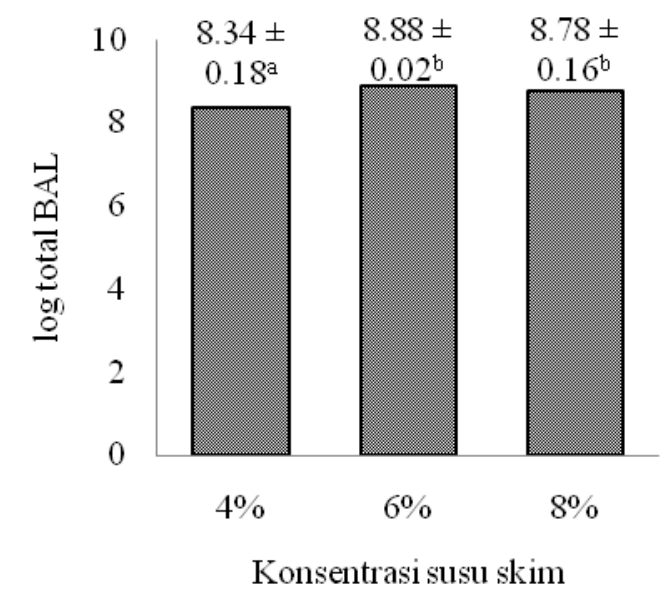

Ket: Notasi huruf superscript yang berbeda pada grafik menunjukkan perbedaan yang signifikan $(\mathrm{p}<0.05)$

Gambar 5. Pengaruh konsentrasi susu skim terhadap total BAL minuman fermentasi daun jeruk nipis.

Berdasarkan Gambar 5, hasil menunjukkan bahwa konsentrasi susu skim $4 \%$ menghasilkan minuman fermentasi daun jeruk nipis dengan total bakteri asam laktat yang berbeda signifikan $(\mathrm{p}<0.05)$ daripada minuman fermentasi daun jeruk nipis dengan konsentrasi susu skim sebesar 6\% atau 8\%. Sintasari et al. (2014) menjelaskan bahwa dengan adanya peningkatan konsentrasi susu skim sebagai sumber 
energi, pertumbuhan bakteri asam laktat akan meningkat.

\section{Formulasi Terpilih}

Hasil analisis nilai $\mathrm{pH}$, nilai TAT, dan total BAL dibandingkan dengan beberapa standar minuman fermentasi sehingga formulasi terpilih minuman fermentasi daun jeruk nipis dapat ditentukan. Beberapa standar acuan produk minuman fermentasi dapat dilihat pada Tabel 1.

Tabel 1. Standar minuman fermentasi

\begin{tabular}{cccc}
\hline Standar & Nilai pH & $\begin{array}{c}\text { Nilai } \\
\text { TAT }(\%)\end{array}$ & $\begin{array}{c}\text { Total BAL } \\
(\mathrm{CFU} / \mathrm{ml})\end{array}$ \\
\hline BSN & - & $0.2-0.9$ & 106 \\
$(2009)$ & & & 107 \\
CODEX & - & $>0.6$ & 106 \\
$(2003)$ & & & 107 \\
FSANZ & $<4.5$ & - & \\
$(2014)$ & & - & 107 \\
JETRO & - & - & \\
$(2011)$ & & & \\
\hline
\end{tabular}

Konsentrasi gula dan skim yang terpilih dalam penelitian pembuatan minuman fermentasi daun jeruk nipis adalah 4\%. Hasil uji statistik menunjukkan bahwa minuman fermentasi daun jeruk nipis yang menggunakan konsentrasi susu skim 4\% dan konsentrasi gula 4\% memiliki nilai $\mathrm{pH}$, nilai total asam tertitrasi, dan total bakteri asam laktat yang sudah sesuai dengan standar

\section{Karakteristik Gizi Minuman Fermentasi Daun Jeruk Nipis}

Analisis proksimat minuman fermentasi daun jeruk nipis terpilih hasil dapat dilihat pada Tabel 2 .

Tabel 2. Komposisi zat gizi minuman fermentasi daun jeruk nipis

\begin{tabular}{cc}
\hline Zat gizi & Hasil \\
\hline Kadar air & $91.34 \%$ \\
Kadar abu & $0.32 \%$ \\
Lemak total & $0.00 \%$ \\
Protein & $1.35 \%$ \\
Karbohidrat total & $6.99 \%$ \\
\hline
\end{tabular}

Hasil analisis proksimat menunjukkan bahwa minuman fermentasi daun jeruk nipis yang dihasilkan telah sesuai dengan persyaratan komposisi zat gizi minuman fermentasi menurut SNI.

Tabel 3. Syarat mutu minuman susu fermentasi menurut SNI 7552:2009

\begin{tabular}{lcc}
\hline \multirow{2}{*}{ Kriteria uji } & \multicolumn{2}{c}{ Persyaratan } \\
\cline { 2 - 3 } & Normal & Tanpa lemak \\
\hline Lemak & Min 0.6\% & Maks. 0.5\% \\
(b/b) & \\
Protein (N x & Min 1.0\% \\
6.38) (b/b) & \\
Abu (b/b) & Maks 1.0\% \\
\hline
\end{tabular}

Minuman fermentasi daun jeruk nipis tidak dapat dikategorikan sumber protein. Kandungan proteinnya tidak memenuhi standar klaim zat gizi, yaitu sebesar $1.35 \%$, lebih kecil dari standar 5\%. Rendahnya kandungan protein pada minuman fermentasi daun jeruk nipis dapat disebabkan karena adanya aktivitas protease yang dihasilkan oleh bakteri asam laktat selama proses fermentasi (Nazarni et al. 2016; Adetuyi dan Ibrahim 2014; Chandan dan Kilara 2013).

Tabel 4 Standar klaim zat gizi (CAC, 1997)

\begin{tabular}{lcl}
\hline Komponen & Klaim & \multicolumn{1}{c}{ Kondisi } \\
\hline Lemak & Rendah & $<3 \mathrm{~g} / 100 \mathrm{~g}$ (solid) \\
& & $<1.5 \mathrm{~g} / 100 \mathrm{ml}$ (liquid) \\
& & $<0.5 \mathrm{~g} / 100 \mathrm{~g}$ (solid) \\
& $<0.5 \mathrm{~g} / 100 \mathrm{ml}$ (liquid) \\
Protein & Sumber & $>10 \% \mathrm{NRV} / 100 \mathrm{~g}$ (solid) \\
& & $>5 \% \mathrm{NRV} / 100 \quad \mathrm{ml}$ \\
& & $($ liquid) \\
& & $>20 \% \mathrm{NRV} / 100 \mathrm{~g}(\mathrm{solid})$ \\
& & $>10 \% \mathrm{NRV} / 100 \quad \mathrm{ml}$ \\
& Tinggi & $($ liquid)
\end{tabular}

Berdasarkan Tabel 4, minuman fermentasi daun jeruk nipis terpilih dikategorikan sebagai produk pangan yang 
bebas lemak karena lebih rendah dari standar klaim $0.5 \%$, yaitu sebesar $0 \%$ (tidak mengandung lemak), sehingga dapat diklaim bahwa minuman fermentasi daun jeruk nipis merupakan produk pangan bebas lemak. Hal ini dapat dikarenakan kandungan lemak awal pada bahan nabati yang relatif rendah dibandingkan kandungan lemak awal bahan hewani (Marsh et al. 2014).

\section{HPLC Total Asam Laktat}

Hasil analisis asam laktat minuman fermentasi daun jeruk nipis dengan HPLC menunjukkan bahwa minuman fermentasi daun jeruk nipis memiliki kandungan asam laktat sebesar $18992.77 \mathrm{ppm}$ atau setara dengan 1.90\%. Cheng (2010) menjelaskan bahwa kandungan asam laktat minuman fermentasi umumnya adalah sebesar $0.9 \%$.

Gezginc et al. (2015) menjelaskan bahwa perbedaan kandungan asam laktat dipengaruhi oleh jenis dan persentase bakteri asam laktat yang digunakan. Setiap jenis bakteri asam laktat memiliki kondisi optimalnya masing-masing, dan banyak atau sedikitnya jumlah bakteri asam laktat yang digunakan berpengaruh terhadap banyak atau sedikitnya jumlah glukosa yang dikonversi menjadi asam laktat.

\section{Total Kapasitas Antioksidan, Total Fenolik, dan Total Flavonoid}

Hasil uji total kapasitas antioksidan, total fenolik, dan total flavonoid menunjukkan bahwa minuman fermentasi daun jeruk nipis memiliki rata-rata nilai total kapasitas antioksidan, total fenolik, dan total flavonoid sebesar 12.47 mgVCE/L, 33.49 mgGAE/100ml, dan $223.75 \mathrm{mgQE} / \mathrm{L}$. Hasil fermentasi terhadap nilai total kapasitas antioksidan, total fenolik, dan total flavonoid seperti disajikan Gambar 6.

Berdasarkan Adetuyi dan Ibrahim (2014), fermentasi dapat meningkatkan total fenolik dan total flavonoid sehingga juga dapat meningkatkan aktivitas antioksidan.
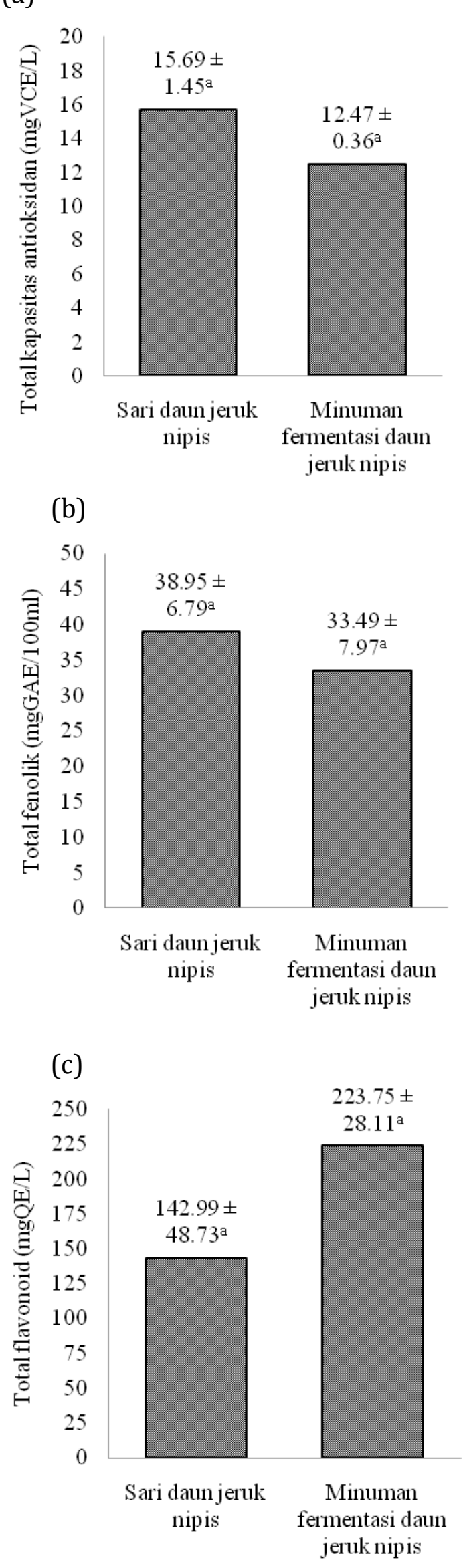
Ket: Notasi huruf superscript yang berbeda pada grafik menunjukkan perbedaan yang signifikan $(p<0.05)$

Gambar 6. Pengaruh fermentasi terhadap (a) total kapasitas antioksidan, (b) total fenolik, dan (c) total flavonoid minuman fermentasi daun jeruk nipis.

Bakteri asam laktat memiliki kemampuan untuk merombak glukosa menjadi asam organik sebagai metabolit primer dan senyawa fenol sebagai metabolit sekunder. Nazarni et al. (2016) menjelaskan bahwa proses fermentasi dapat menyebabkan pelepasan enzim microbial, seperti glukosidase, amilase, lipase, dan esterase, yang memiliki peranan dalam pembentukkan komponen fitokimia bebas, seperti flavonoid, tanin, alkaloid, dan fenilpropanoid.

Total fenolik, flavonoid, dan kapasitas antioksidan minuman fermentasi daun jeruk nipis lebih kecil atau sama dengan minuman daun jeruk nipis yang tidak difermentasi. Suhu $80^{\circ} \mathrm{C}$ pada proses pasteurisasi dapat mendegradasi sejumlah komponen kelompok fenolik atau flavonoid. Hal ini karena beberapa komponen aktif bersifat tidak stabil pada suhu tinggi (Sharma et al. 2015). Berdasarkan Paliyath et al. (2011) dan Nazarni et al. (2016), hal ini juga mungkin dapat terjadi karena terjadinya proses degradasi atau depolimerisasi komponen fenolik menjadi monomer yang lebih kecil sebagai mekanisme detoksifikasi terhadap bakteri asam laktat yang digunakan.

\section{Uji Skoring}

Penilaian karakteristik minuman fermentasi daun jeruk nipis dilakukan terhadap parameter warna, rasa asam, rasa pahit, aroma, dan tekstur (Gambar 7).

Warna agak hijau muncul sebagai hasil perpaduan antara sari daun jeruk nipis yang berwarna hijau muda dengan susu yang berwarna putih. Sari daun jeruk nipis $5 \%$ tidak dapat memberikan kontribusi yang besar terhadap warna akhir minuman fermentasi karena proporsi air yang tinggi.

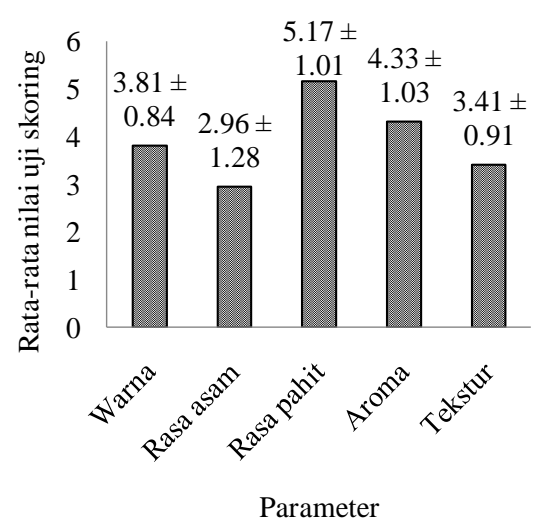

Gambar 7. Rata-rata nilai uji skoring minuman fermentasi daun jeruk nipis

Pada parameter rasa, penilaian rasa minuman fermentasi yang agak tidak asam oleh panelis tidak sebanding dengan nilai $\mathrm{pH}$ minuman fermentasi yang berada di bawah 4.5, tidak seperti pada parameter aroma. Terbentuknya asam laktat melalui jalur glikolisis EMP yang akan terdisosiasi menjadi ion $\mathrm{H}^{+}$dapat menurunkan nilai $\mathrm{pH}$ (Adetuyi dan Ibrahim, 2014). Rasa asam pada minuman fermentasi daun jeruk nipis tertutupi oleh rasa pahit. Rasa pahit memiliki nilai threshold terkecil (Branen et al. 2002). Rasa pahit muncul sebagai akibat adanya kandungan komponen aktif pada daun jeruk nipis, seperti flavonoid, tanin (Nollet dan Toldra 2013), terpene (Hui dan Evranuz 2016), saponin (Ezeabara et al. 2014a), glikosida, dan alkaloid (Brimer 2011).

Pada parameter tekstur, tekstur yang dihasilkan agak tidak kental dikarenakan proporsi daun jeruk nipis yang digunakan untuk membuat sari daun jeruk nipis 5\% hanya sedikit. Setiono (2016) menjelaskan bahwa semakin tinggi proporsi bahan dan semakin sedikit proporsi air, minuman fermentasi yang dihasilkan akan memiliki tekstur yang kental. Tekstur kental dapat dihasilkan karena terbentuknya asam 
laktat sehingga menyebabkan terjadinya koagulasi (Tamang dan Kailasapathy, 2010).

\section{Uji Hedonik}

Uji tingkat kesukaan minuman fermentasi daun jeruk nipis dilakukan terhadap parameter warna, rasa, aroma, tekstur, dan keseluruhan (Gambar 8).

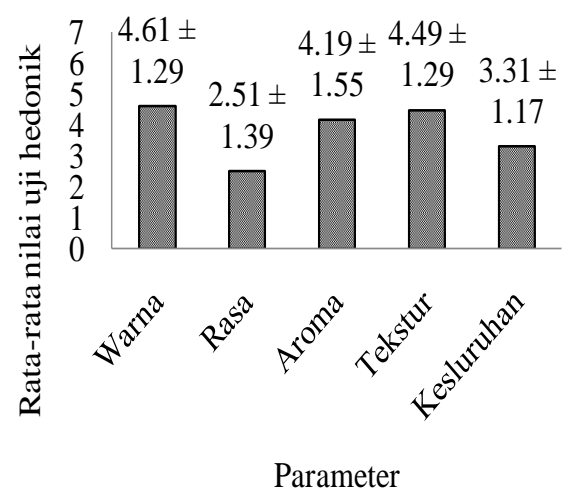

Gambar 8. Rata-rata nilai uji hedonik minuman fermentasi daun jeruk nipis.

Minuman fermentasi daun jeruk nipis memiliki warna yang agak disukai, rasa yang agak tidak disukai, aroma yang netral, dan tekstur yang agak disukai. Rasa tidak disukai karena adanya dominasi rasa pahit yang tidak disukai (Kringelbach dan Berridge, 2010). Pada parameter tekstur, minuman fermentasi daun jeruk nipis memiliki tekstur yang agak disukai karena teksturnya agak tidak kental. Tekstur minuman yang kental kurang disukai karena dapat menekan keinginan untuk makan (McCrickerd et al. 2012).

Tingkat kesukaan secara keseluruhan dari minuman fermentasi daun jeruk nipis adalah agak tidak disukai. Rasa dan tekstur dapat mempengaruhi penerimaan keseluruhan produk minuman fermentasi (Setiono 2016).

\section{KESIMPULAN}

Konsentrasi sari daun jeruk nipis terpilih sebesar 5\% tidak menunjukkan adanya aktivitas antimikroba dalam menghambat pertumbuhan $S$. thermophilus dan L. plantarum. Konsentrasi gula dan susu skim terpilih minuman fermentasi daun jeruk nipis adalah $4 \%$.

Minuman fermentasi daun jeruk nipis merupakan produk pangan bebas lemak dengan kandungan total asam laktat sebesar 18992.77 ppm.. Kandungan total kapasitas antioksidan, total fenolik, dan total flavonoid minuman fermentasi daun jeruk nipis adalah sebesar $12.47 \mathrm{mgVCE} / \mathrm{L}$, $33.49 \mathrm{mgGAE} / \mathrm{L}$, dan $223.75 \mathrm{mgQE} / \mathrm{L}$. Proses fermentasi tidak dapat meningkatkan kandungan total kapasitas antioksidan, fenolik, dan flavonoid secara signifikan.

Minuman fermentasi daun jeruk nipis terpilih agak tidak disukai panelis. Minuman fermentasi daun jeruk nipis memiliki karakteristik rasa agak tidak asam, namun cenderung pahit yang agak tidak disukai, warna agak hijau yang agak disukai, aroma agak asam, dan tekstur agak tidak kental yang agak disukai.

\section{DAFTAR PUSTAKA}

Adetuyi, F.O. dan Ibrahim, T.A. 2014. Effect of Fermentation Time on The Phenolic, Flavonoid and Vitamin C Contents and Antioxidant Activities of Okra (Abelmoschus esculentus) Seeds. Nigerian Food Journal 32(2): 128-137.

AOAC. 1995. "Official Methods of Analysis" $16^{\text {th }}$ ed. AOAC, Maryland.

AOAC. 2005. "Official Methods of Analysis" $18^{\text {th }}$ ed. AOAC, Maryland.

Branen, A.L., Davidson, P.M., Salminen, S., dan Throngate III, J.H. 2002. "Food Addittives". Marcel Dekker, New York.

Brimer, L. 2011. "Chemical Food Safety". CAB International, Oxford.

BSN. 2009. "SNI 7552:2009 Minuman Susu Fermentasi Berperisa". BSN, Jakarta. 
Caballero, B., Finglas, P.M., dan Toldra, F. 2016. "Encyclopedia of Food and Health". Academic Press, Massachusetts.

Chandan, R., Kilara, A., dan Shah, N. 2008. "Dairy Processing \& Quality Assurance". Wiley-Blackwell, Iowa.

Chandan, R. dan Kilara, A. 2013. "Manufacturing Yogurt and Fermented Milks" $2^{\text {nd }}$ ed. John Wiley \& Sons, Iowa.

Cheng, H. 2010. Volatile Flavor Compounds in Yogurt: A Review. Critical Reviews in Food Science and Nutrition 50: 938-950.

Codex Alimentarius Commission (CAC). 2003. "Codex Standard for Fermented Milks: Codex Stan 2432003". Codex Alimentarius Commission.

Codex Alimentarius Commission (CAC). 1997. "Guidelines for Use of Nutrition and Health Claims (CAC/GL 23-1997)". Codex Alimentarius Commission.

Ebnesajjad, S. 2013. "Plastic Films in Food Packaging: Materials, Technology, and Applications". William Andrew, Massachusetts.

Ezeabara, C.A., Okeke, C.U., dan Aziagba, B.0. 2013. Flavonoid Content of Citrus Species Grown in Awka, Anambra State, Southeastern Nigeria. Inter. J. Agri. Biosci. 2(3): 103-107.

Ezeabara, C.A., Okeke, C.U., Aziagba, B.O., Ilodibia, C.V., dan Emeka, A.N. 2014. Determination of Saponin Content of Various Parts of Six Citrus Species. Inter. Res. J. Pure \& App. Chem. 4(1): 137-143.

Food Standards Australia New Zealand (FSANZ). 2014. "Australia New Zealand Food Standards Code". Food Standards Australia New Zealand.

Frank, J.F. dan Yousef, A.E. 2004. "Standard Methods for The Examination of Diary Product" $17^{\text {th }}$ ed. American
Public Health Association, Washington.

Gezginc, Y., Topcal, F., Comertpay, S., Akyol, I. 2015. Quantitative Analysis of The Lactic Acid and Acetaldehyde Produced by Streptococcus thermophilus and Lactobacillus bulgaricus Strains Isolated from Traditional Turkish Yogurts Using HPLC. J. Dairy Sci. 98: 1-9.

Haq, G.I., Permanasari, A., dan Sholihin, H. 2010. Efektivitas Penggunaan Sari Buah Jeruk Nipis terhadap Ketahanan Nasi. Jurnal Sains dan Teknologi Kimia 1(1): 44-58.

Hartati, A.I., Pramono, Y.B., dan Legowo, A. 2012. Lactose and Reduction Sugar Concentrations, $\mathrm{pH}$ and The Sourness of Date Flavored Yogurt Drink as Probiotic Beverage. J. App. Food Technol. 1(1): 1-3.

Hui, Y.H. dan Evranuz, E.O. 2016. "Handbook of Vegetable Preservation and Processing" 2nd ed. CRC Press, Florida.

Hui, Y.H., Evranuz, E.O., Lopez, F.N.A, Fan, L., Hansen, A.S., Flores, M.E.J., Rakin, M., Schwan, R.F., dan Zhou, W. 2012. "Handbook of Plant-Based Fermented Food and Beverage Technology" $2^{\text {nd }}$ ed. CRC Press, Florida.

Jamal, Y., Pariwidjayanti, A.M., dan Agusta, A. 2012. Chemical Compositions and Antibacterial Effect of Essential Oil of Key Lime Leaves (Citrus aurantiifolia Swingle: Rutaceae). Annales Bogorienses 16(2): 23-28.

Japan External Trade Organization (JETRO). 2011. "Specifications and Standards for Foods, Food Additives, etc.". Japan External Trade Organization.

Kringelbach, M.L. dan Berridge, K.C. 2010. "Pleasures of The Brain". Oxford University Press, New York.

Lamien-Meda, A., Lamien, C.E., Compaore, M.M.Y., Meda, R.N.T., Kiendrebeogo, M., Zeba, B., Millogo, J.F., dan 
Nacoulma, O.G. 2008. Polyphenol Content and Antioxidant Activity of Fourteen Wild Edible Fruits from Burkina Faso. Molecules 13(3): 581-594.

Lu, J.J., Bao, J.L., Chen, X.P., Huang, M., dan Wang, Y.T. 2012. Alkaloids Isolated from Natural Herbs as The Anticancer Agents. Evidence-Based Complementary and Alternative Medicine 2012: 1-12.

Mardianto, M. 2015. Peranan Minuman Fermentasi Daun Sirsak (Annona muricata L.) sebagai Antikolesterol pada Tikus Sprague Dawley. Skripsi, Universitas Pelita Harapan, Karawaci.

Marsh, A., Hill, C., Ross, P., dan Cotter, P. 2014. Fermented Beverages with Health-Promoting Potential: Past and Future Perspectives. Trends in Food Science \& Technology 38: 113-124.

McCrickerd, K., Chambers, L., Brunstrom, J.M., dan Yeomans, M.R. 2012. Subtle Changes in The Flavour and Texture of A Drink Enhance Expectations of Satiety. Flavour $1(20)$.

Meilgaard, M., Civille, G.V., dan Carr, B.T. 2007. "Sensory Evaluation Techniques" $4^{\text {th }}$ ed. CRC Press, Florida.

Murdani, R. 2014. Keefektivan Daya Bunuh Ekstrak Daun Jeruk Nipis (Citrus aurantiifolia) terhadap Kematian Larva Nyamuk Aedes aegypti Instar III. Skripsi, Universitas Muhammadiyah Surakarta, Surakarta.

Nazarni, R., Purnama, D., Umar, S., dan Eni, H. 2016. The Effect of Fermentation on Total Phenolic, Flavonoid and Tannin Content and Its Relation to Antibacterial Activity in Jaruk Tigarun (Crataeva nurvala, Buch HAM). International Food Research Journal 23(1): 309-315.
Nollet, L.M.L. dan Toldra, F. 2013. "Food Analysis by HPLC" $3^{\text {rd }}$ ed. CRC Press, Florida.

Paliyath, G., Bakovic, M., dan Shetty, K. 2011. "Functional Foods, Nutraceuticals and Degenerative Disease Prevention". WileyBlackwell, West Sussex.

Reddy, J., Jalli, R.D., Jose, B., dan Gopu, S. 2012. Evaluation of Antibacterial and Antioxidant Activities of The Leaf Essential Oil and Leaf Extracts of Citrus aurantiifolia. Asian Journal of Biochemical and Pharmaceutical Research 2(2): 346-354.

Sharma, K., Ko, E.Y., Assefa, A.D., Ha, S., Nile, S.H., Lee, E.T., dan Park, S.W. 2015. Temperature-Dependent Studies on The Total Phenolics, Flavonoids, Antioxidant Activities, and Sugar Content in Six Onion Varieties. Journal of Food and Drug Analysis 23: 243-252.

Sintasari, R.A., Kusnadi, J., dan Ningtyas, D.W. 2014. Pengaruh Penambahan Konsentrasi Susu Skim dan Sukrosa terhadap Karakteristik Minuman Probiotik Sari Beras Merah. Jurnal Pangan dan Agroindustri 2(3): 6575.

Soccol, C.R., Pandey, A., dan Larroche, C. 2013. "Fermetation Processes Engineering in The Food Industry". CRC Press, Florida.

Soulef, K., Abdelouahab, Y., dan Dalal, B. 2014. Effect of Glycosides Extract of The Medicinal Plant Glycyrrhiza glabra L. from The Region of Mlilli (Southeast of Algeria) on The Growth of Some Human Pathogenic Bacteria. Journal of Scientific \& Innovative Research 3(1): 28-34.

Subenthiran, S., Choon, T.C., Cheong, K.C., Thayan, R., Teck, M.B., Muniandy, P.K., Afzan, A., Abdullah, N.R., dan Ismail, Z. 2013. Carica papaya Leaves Juice Significantly Accelerates The Rate of Increase in Platelet Count among Patients with 
Dengue Fever and Dengue Haemorrhagic Fever. EvidenceBased Complementary and Alternative Medicine: 1-7.

Sugiwati, S. 2005. Aktivitas Antihiperglikemik dari Ekstrak Buah Mahkota Dewa (Phaleria macrocarpa (Scheff.) Boerl) sebagai Inhibitor Afa-Glukosidase. Skripsi, Institut Pertanian Bogor, Bogor.

Tamang, J.P. dan Kailasapathy, K. 2010. "Fermented Foods and Beverages of The World". CRC Press, Florida.

Tangkanakul, P., Auttaviboonkul, P., Niyomwit, B., Lowvitoon, N., Charoenthamawat, P., dan Trakoontivakom, G. 2009. Antioxidant Capacity, Total Phenolic Content, and Nutritional Composition of Asian Foods After Thermal Processing. International Food Research Journal 16: 571-580.

Thompson, M. 2014. "Superfood for Life: Cultured and Fermented Beverages". Fair Winds Press, Massachusetts.

Yendo, A.C.A., De Costa, F., Gosmann, G., dan Neto, A.G.F. 2010. Production of Plant Bioactive Triterpenoid Saponins: Elicitation Strategies and Target Genes to Improve Yields. Molecular Biotechnology 46(1): 94104.

Zare, F., Orsat, V., Champagne, C., Simpson, B.K., dan Boye, J.I. 2012. Microbial and Physical Properties of Probiotic Fermented Milk Supplemented with Lentil Flour. Journal of Food Research 1(1): 94-10 